\title{
Nitrogen Utilization in Creeping Bentgrass
}

\author{
Y. Kuo \\ T. W. Fermanian \\ D. J. Wehner
}

\begin{abstract}
N}$ utilization, including plant dry weight (DW) production, total $\mathrm{N}$ and nitrate $\mathrm{N}\left(\mathrm{NO}_{3}-\mathrm{N}\right)$ content accumulation, $\mathrm{N}$ utilization efficiency (NUE), root absorption efficiency (RAE), reduced $\mathrm{N}$ accumulation, and nitrate assimilation capacity (NAC) were determined for creeping bentgrass cultivars grown in hydroponic culture. Possible mechanisms affecting $\mathrm{N}$ utilization including nitrate reductase activity (NRA) and root morphology were also examined. Four cultivars, selected from an initial screening of creeping bentgrasses were grown under both low and high levels of $\mathrm{N}$ in a flowing solution culture system. The relationship between NUE and plant growth for two different creeping bentgrass cultivars was investigated through tissue culture. The results indicate a genotypic variation in $\mathrm{N}$ utilization and absorption. The NAC was not the primary factor involved in genotypic differences in NUE. However, NRA was probably one of the mechanisms for the regulation of NUE. $\mathrm{N}$ utilization was affected by the level of $\mathrm{N}$ supplied level and environmental conditions. Plants grown under low levels of $\mathrm{N}$ had longer roots compared to plants grown under medium or high levels of $\mathrm{N}$ for either cultivar. The results suggest that root
\end{abstract}

Y. Kuo is affiliated with the Chinese Culture University, Department of Landscape Architecture, 55 Hwa-Ken Road, Yang Ming Shan, Taipei, Taiean, ROC.

T. W. Fermanian is affiliated with the Department of Natural Resource and Environmental Science, University of Illinois, 1102 South Goodwin Avenue, Urbana, IL 61801.

D. J. Wehner is affiliated with the College of Agriculture, Cal Poly State University, San Luis Obispo, CA 93407.

Please address correspondence to T. W. Fermanian at the above address (E-mail: fermo@uiuc.edu).

Contribution from the Illinois Agricultural Experiment Station, Urbana.

This study was partially supported by the Illinois Turfgrass Foundation. 
formation was probably one of the mechanisms for regulating the nitrate utilization in creeping bentgrass.

KEYWORDS. Creeping bentgrass, nitrogen efficiency, cultivars, nitrate reductase

ABBREVIATIONS. NUE, nitrogen utilization efficiency; RAE, root absorption efficiency; NRA, nitrate reductase activity

Creeping bentgrass (Agrostis palustris Huds.) is native to Eurasia and widely used throughout the world. Because of its low mowing height, prostrate growth and high density, it is used on golf course putting greens. The $\mathrm{N}$ fertility requirement varies from 4 to $7 \mathrm{~g} \mathrm{~m}^{-2}$ per growing month on greens (Beard, 1973). However, many turfgrass scientists feel that golf course bentgrasses are too dark green, with excessive fertilization resulting in over stimulation. Optimal fertilization can reduce the irrigation requirement, thatch buildup, mowing frequency, weed invasion, disease incidence, improve the tolerance of the turf, and reduce ground water pollution (Agnew, 1992; Decker and Decker, 1988).

In general, $\mathrm{N}$ use efficiency of plants are composed of two components which are NUE (defined as the quantity of dry matter produced per unit of tissue $\mathrm{N}$ ) and $\mathrm{N}$ absorption efficiency (defined as total plant $\mathrm{N}$ accumulated per unit of $\mathrm{N}$ supplied) (Moll et al., 1982). The NUE is affected by genotype and environmental factors. Several studies indicated that high $\mathrm{N}$ utilization efficient cultivars and higher $\mathrm{N}$ application also produced higher NRA (Bar-Akin et al., 1970; Ingemarsson, 1987). Nitrate absorbed by plant roots is first reduced to ammonium before incorporation into amino acids which are controlled by nitrite and nitrate reductase. The capacity for nitrate reduction varies among higher plant species and cultivars (Smirnoff et al., 1984). Nitrate reductase is an unstable enzyme which is affected by the quantity of substrate (nitrate itself), genotype, age and organ of the plant, and climatic conditions. The seasonal NRA level of a crop is difficult to determine. Increasing supplied $\mathrm{N}$ nutrition can cause the accumulation of nitrate in tissue and also increases the NRA. Differences between 
species and the site of $\mathrm{N}$ assimilation have been discussed in the past (Andrew, 1986; Stewart et al., 1987). A correlation between NRA and nitrate content was reported by Feil et al. (1993). It was assumed that the NRA and nitrate concentration of a cultivar is generally inversely related, although this was not supported in their study.

Plants take up mineral nutrients from the soil mainly through their roots, the principal organ of uptake. Root development may be one of the mechanisms to explain the difference in NUE among cultivars (Bole, 1973). The relationship between root architecture and the efficiency of capturing nutrients has been discussed in previous studies (Robinson, 1986; Kuo et al., 1994; Warncke and Barber, 1974). Boeker and Boberfeld (1974) found that the amount of roots in unfertilized turf were significantly deeper than roots in fertilized turf plots. They concluded that an increasing $\mathrm{N}$ concentration in the root environment makes them expand less. Foehse and Jungk (1983) found that the root hair formation for three different crops was influenced by the nitrate content. The formation of root hairs is one mechanism for regulating the nutrient uptake of plants. According to Robinson (1986), the efficiency of nutrient uptake depends mainly on root length, while Feil et al. (1990) found a close relationship between the reduction of nitrate and root surface area. Tissue culture techniques provide a model system to screen nutrient use efficiency in vitro for different plant species. Evans (1993) reported that a reduction in the $\mathrm{N}$ level in the medium tended to produce taller plants with longer internodes, larger leaves with less chlorophyll, but the plant fresh weight did not change. Kuo et al. (1994) found that the root tip structures of creeping bentgrass cultivars were changed under high levels $\left(3 \% \mathrm{Na}_{2} \mathrm{SO}_{4}\right)$ of supplied salt. However, some disagreement still exists as to whether root morphology or nitrate concentrations limit the efficiency of nitrate utilization (Feil et al., 1990). Unfortunately, little information is available on which characteristics of turfgrass determine the efficiency of nitrate uptake.

In this study, the $\mathrm{N}$ utilization of creeping bentgrass grown under different levels of $\mathrm{N}$ fertilization, the role of nitrate reductase, the site of $\mathrm{N}$ assimilation, and some of the relationships between DW production, $\mathrm{N}$ content, NUE, RAE, NRA, and nitrate content in plant tissues were investigated. The other investigation was to relate the NUE of two creeping bentgrass cultivars to their root and shoot development over a range of $\mathrm{N}$ levels through tissue culture methods. 


\section{MATERIALS AND METHODS}

\section{Flowing Solution Culture}

Seeds of 4 bentgrass cultivars, 'National', 'SR 1020', 'Penncross', and 'Putter', were sown in a plastic tray $\left(25 \times 52 \mathrm{~cm}^{2}\right)$ containing medium-grade vermiculite. These seeds were covered with a thin layer of the same medium to reduce desiccation. After 16 to $18 \mathrm{~d}$, seedlings were removed from the vermiculite and any media attached to the roots was washed off with distilled water. Seedlings of uniform size (root length about $2.5 \mathrm{~cm}$ ), were placed on the center of a sterilized Dispo plug (Scientific Products Co., San Jose, CA) $(10 \mathrm{~mm}$ in height $\times$ $20 \mathrm{~mm}$ in diameter) as support. The Dispo plugs holding seedlings were placed in a hole cut in a blue-styrofoam sheet $(30 \times 43 \times 2.5$ $\mathrm{cm}^{3}$ ) that floated on the surface of 151 of $10 \%(\mathrm{v} / \mathrm{v})$ Pellett and Roberts' solution (Pellett and Roberts, 1963) that contained $10 \mathrm{ppm}$ of $\mathrm{N}$ in plastic tanks where the roots were submerged in the aerated solution. Plants were acclimated in the tanks for five days before transplanting to the final evaluation systems. Seedlings of uniform size were removed from the tanks and placed in PVC pots $(20 \mathrm{~cm}$ in height $\times 10 \mathrm{~cm}$ in diameter). A thin-knock out cap $(10 \mathrm{~cm})$ served as the lid. The solution was recycling from a storage tank (120 l), and solution in the recycling tanks were renewed once a week. Four holes, the size of the Dispo plug, were drilled in to each lid. Each pot contained 1.61 of solution. The solution consisted of $50 \%$ Pellett and Roberts' solution but with the $\mathrm{N}$ concentrations at $3 \mathrm{ppm}$ for low $\mathrm{N}$ level and $50 \mathrm{ppm}$ for high $\mathrm{N}$ level. For the low $\mathrm{N}$ level solution the potassium concentration was kept the same as the high $\mathrm{N}$ level by adding $\mathrm{KH}_{2} \mathrm{PO}_{4}$. During the experimental period, $\mathrm{KNO}_{3}$ was added to maintain the desired $\mathrm{N}$ level after the solution was measured by spectrophotometer (Beckman DU-65) at $210 \mathrm{~nm}$. Solution $\mathrm{pH}$ were adjusted to 5.5 to 6.5 (a pocket pH meter, Analytical Measurements Inc. Model 107) by adding $0.5 \mathrm{~N} \mathrm{HCl}$. Three high pressure vapor sodium lights with an average intensity of $424 \mathrm{~mol} \mathrm{~m}^{-2} \mathrm{~s}^{-1}$ were supplied at a $14 / 10$, day/night of photoperiod.

\section{N Determination}

Total $N$ determination. Plants were harvested after 6 weeks. Samples were divided into root and shoot components and dried in an oven 
at $80^{\circ} \mathrm{C}$ for $72 \mathrm{hrs}$. The dry weight of each was recorded. Sample tissues were kept in an oven before grinding. Dry tissues were ground with a Wiley-Thomas Mill grinder to pass through a 40 mesh screen. The ground tissue was used to measure tissue $\mathrm{N}$ by the Micro-kjeldahl method (Cataldo et al., 1974).

Determination of nitrate in plant tissue. About $150 \mathrm{mg}$ of dried tissue powders was placed in $125 \mathrm{ml}$ erlenmeyer flasks. Twenty-five $\mathrm{ml}$ of hot water $\left(80^{\circ} \mathrm{C}\right)$ was added to the flask, it was sealed with parafilm, and shook for $30 \mathrm{~min}$ on a wrist-action shaker.The extract was filtrated through Watman \#2 filter paper into a beaker. The remaining tissue was quantitatively transferred to the flask with a second $25 \mathrm{ml}$ aliquot of hot water. A $0.2 \mathrm{ml}$ aliquot was mixed with $0.8 \mathrm{ml}$ of the $0.5 \% \mathrm{SA}-\mathrm{H}_{2} \mathrm{SO}_{4}$ mixture for $20 \mathrm{~min}$ at room temperature to cool the samples. Nineteen $\mathrm{ml}$ of $2 \mathrm{~N} \mathrm{NaOH}$ was added for color development at room temperature about a hour. Nitrate content was measured colorimetrically at $410 \mathrm{~nm}$ (Cataldo et al., 1975)

In vivo NRA assay. The protocol used for the NRA assay was developed by Harper and Hageman (1972). Approximately $0.5 \mathrm{~g}$ of fresh leaf or root segments (tip of the tissues) were transferred to test tubes. Five $\mathrm{ml}$ of the incubation media was also added. The incubation media contained nitrate for potential activity measurement that consisted of $0.5 \mathrm{mM}$ of $\mathrm{K}_{2} \mathrm{SO}_{4}, 100 \mathrm{mM}$ of $\mathrm{K}_{2} \mathrm{HPO}_{4}$, and $1 \%$ (V/V) of n-propanol ( $\mathrm{pH} 7.5)$. A stainless steel wire screen (20 mesh) was placed in each tube to hold the tissue below the solution surface. The samples were then vacuum filtrated for $1.5 \mathrm{~min}$ in a vacuum desiccator. Air was rapidly reintroduced and the procedure was repeated. Samples were then transferred to a shaking water bath and incubated for $1 \mathrm{hr}$ at $30^{\circ} \mathrm{C}$ in the dark. After incubation, $0.4 \mathrm{ml}$ of color reagents [ $2 \mathrm{ml}$ of $1 \%$ sulfanilic acid in $1.5 \mathrm{~N}$ of $\mathrm{HCl}$ and $2 \mathrm{ml}$ of $0.02 \%$ of $\mathrm{N}$-(1-naphthylethylene diamine) $\cdot 2 \mathrm{HCl}$. The development of color took between 20 to 30 mins. The absorbance was determined at 540 $\mathrm{nm}$ by using a Beckmen (model DU-7) spectrophotometer. The nitrite activity was expressed as $\mu$ moles $\mathrm{NO}_{3} \mathrm{~g}^{-1}$ fresh wt/hr.

\section{Treatments and Experimental Design}

Experiments were conducted twice, once on July, 1994 (EXP1) during which the greenhouse average air temperature was around $32 / 2^{\circ} \mathrm{C}$, day/night, and again on November, 1994 (EXP2) which the greenhouse average air temperature were around $24 / 17^{\circ} \mathrm{C}$, day/night. 
A randomized complete block design was used for both experiments. High pressure vapor sodium lights with mercury halide bulbs were applied at a 14/10, day/night photoperiod. Light intensity from lamps ranged from $600 \mathrm{~mol} \mathrm{~m}^{-2} \mathrm{~s}^{-1}$ in the middle of the bench to $290 \mathrm{~mol}$ $\mathrm{m}^{-2} \mathrm{~s}^{-1}$ at the edges (measured by $\mathrm{Li}-1776$ solar monitor). There were six replications of each treatment for the NUE studies, and four replications of each treatment for the NRA studies. Data were subjected to an analysis of variance. Significant differences among cultivars were evaluated using Fisher's protected least significant difference (LSD) test.

\section{In Vitro Culture}

Nodal stolon segments of the same size (about $25 \mathrm{~mm}$ ) were randomly collected from a solution with a $\mathrm{N}$ concentration of $50 \mathrm{ppm}$ containing two bentgrass cultivars, 'National' (low NUE) and 'Putter' (high NUE). All plants were at a vegetative stage of development. Nodal explants were sterilized in $70 \%$ ethanol for $20 \mathrm{sec}$, followed by $20 \mathrm{~min}$ in $1.05 \% \mathrm{NaOCl}$ then rinsed in sterile distilled water four times. Each explant was placed in a pyrex test tube containing $20 \mathrm{ml}$ of N6 (Chu et al., 1975) (Table 1) media with sucrose, gelrite (Scott Laboratories, Carson, $\mathrm{CA}$ ), and $\mathrm{KNO}_{3}$. The listed concentrations were tested in preliminary experiments. For the low and medium media, Potassium chloride was added to maintain the $\mathrm{K}^{+}$at the same level as in the high $\mathrm{N}$ medium.

Cultures were incubated four weeks under $45 \mathrm{~mol} \mathrm{~m}^{-2} \mathrm{~s}^{-1}$ of light provided by cool white fluorescent lamps with a $12 \mathrm{hr}$ photoperiod. There were 25 replications per treatment. The root length, root number, and shoot length were measured.

\section{RESULTS AND DISCUSSION}

\section{N Determination}

One goal of this study was to confirm any differences in DW production and NUE among the four creeping bentgrass cultivars evaluated in previous experiments. An analysis of root (RDW), shoot (SDW) and whole plant (WDW) dry weight of cultivars, under both $\mathrm{N}$ levels, 
TABLE 1. Components of Pellett and Roberts solution containing different levels (low, medium, and high) of nitrogen $(\mathrm{N})$ used in in vitro cultural experiment.

\begin{tabular}{|c|c|c|c|c|}
\hline \multirow[b]{2}{*}{$\mathrm{KNO}_{3}(g)$} & \multicolumn{4}{|c|}{ Chemicals Concentration ( $m g / L)$} \\
\hline & Fulli & $\begin{array}{c}\text { Low } N \\
0\end{array}$ & $\begin{array}{c}\text { Medium } N \\
1.01\end{array}$ & $\begin{array}{l}\text { High I } \\
5.05\end{array}$ \\
\hline $\mathrm{KH}_{2} \mathrm{PO}_{4}$ & 400.0 & 400.0 & 400.0 & 400.0 \\
\hline $\mathrm{MgSO}_{4}$ & 185.0 & 185.0 & 185.0 & 185.0 \\
\hline $\mathrm{CaCl}_{2} \cdot 2 \mathrm{H}_{2} \mathrm{O}$ & 166.0 & 166.0 & 166.0 & 168.0 \\
\hline $\mathrm{KCl}(g)$ & - & - & 3.73 & 0.7 \\
\hline $\mathrm{MnSO}_{4} \cdot 4 \mathrm{H}_{2} \mathrm{O}$ & 4.4 & 4.4 & 4.4 & 4.4 \\
\hline $\mathrm{ZnSO}_{4} \cdot 7 \mathrm{H}_{2} \mathrm{O}$ & 1.5 & 1.5 & 1.5 & 1.5 \\
\hline $\mathrm{H}_{3} \mathrm{BO}_{3}$ & 1.6 & 1.6 & 1.6 & 1.6 \\
\hline $\mathrm{KI}$ & 0.8 & 0.8 & 0.8 & 0.8 \\
\hline \multicolumn{5}{|l|}{ IRON: } \\
\hline $\mathrm{FeSO}_{4} \cdot 7 \mathrm{H}_{2} \mathrm{O}$ & 28.0 & 28.0 & 28.0 & 28.0 \\
\hline $\mathrm{Na}^{+}$-EDTA & 38.0 & 38.0 & 38.0 & 38.0 \\
\hline \multicolumn{5}{|l|}{ VITAMIN: } \\
\hline Glycine & 2.0 & 2.0 & 2.0 & 2.0 \\
\hline Thiamine- $\mathrm{HCl}$ & 1.0 & 1.0 & 1.0 & 1.0 \\
\hline Pyridoxine- $\mathrm{HCl}$ & 0.5 & 0.5 & 0.5 & 0.5 \\
\hline Nicotinic acid & 0.5 & 0.5 & 0.5 & 0.5 \\
\hline Sucrose $(g / 1)$ & 30.0 & 30.0 & 30.0 & 30.0 \\
\hline Gerlite $(g / 1)$ & 2.2 & 2.2 & 2.2 & 2.2 \\
\hline
\end{tabular}

showed that 'Penncross' was heavier than all the other cultivars in either experiment, except for SDW and WDW under the low N condition in EXP1 where 'Putter' was the heaviest (Table 2a, 2b). The proportion of WDW partitioned to shoots was greater than that partitioned to roots for each cultivar. Under low N conditions, 'Putter' had a SDW:RDW ratio significantly higher than the other cultivars in EXP1.

Under high $\mathrm{N}$ condition 'National' had the highest SDW:RDW ratio among the cultivars in both experiments. This was due to the low RDW of this cultivar. Plants grown under high $\mathrm{N}$ applications produced significantly greater SDW and WDW than plants grown under low $\mathrm{N}$ applications in both experiments. Conversely, plants grown under high $\mathrm{N}$ levels produced less RDW than plants under low $\mathrm{N}$ applications in either experiment. The cultivar $\times \mathrm{N}$ level interaction was significant for WDW and SDW, and the SDW:RDW ratio in EXP1 and SDW:RDW ratio in $\operatorname{EXP2}(p=0.01)$. 
TABLE 2. Plant dry weight (DW) accumulation and partitioning of four creeping bentgrass cultivars (C) in EXP1 (a) and EXP 2 (b) grown under low (3 ppm) and high $(50 \mathrm{ppm})$ levels of $\mathrm{N}$.

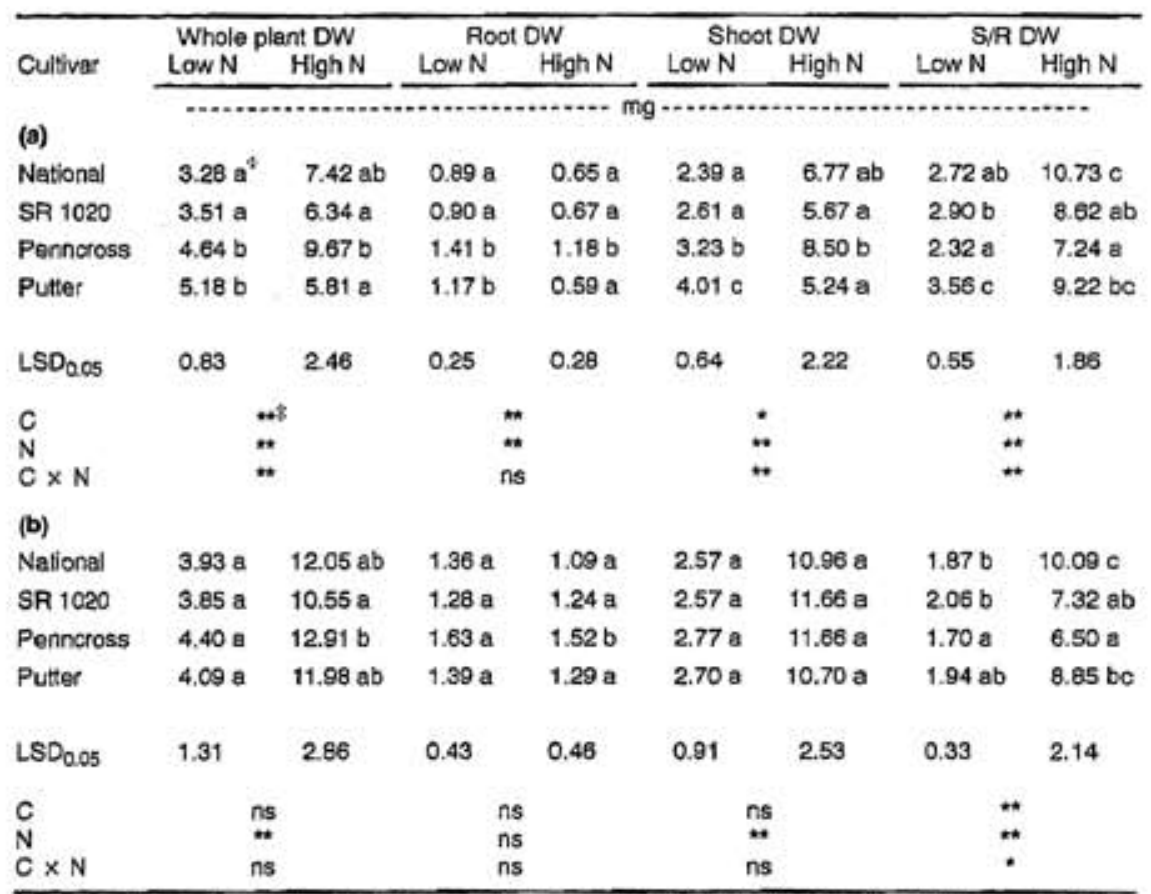

Values within a column followed by the same letter are not significantly different at the S\% level by Fisher's prolested LSD.

$* * *$, ns Significant at $P>0.05, P<0.05$, and $P<0.01$, respectively.

An analysis of the root $\mathrm{N}(\mathrm{RN})$ content of cultivars under either $\mathrm{N}$ conditions showed that 'Penncross' accumulated more $\mathrm{N}$ than all the other cultivars in both experiments, except under low $\mathrm{N}$ levels in EXP2 (Table 3a, 3b). The proportion of whole plant total N (WPN) partitioned to shoots (SN) was higher than partitioned to roots for each cultivar. High $\mathrm{N}$ applications also provided greater accumulated $\mathrm{N}$ than low $\mathrm{N}$ applications in both experiments, except the roots of 'Putter' in EXP1. The cultivars $\times \mathrm{N}$ level interaction was significant for both WPN and SN $(p=0.05)$ in EXP1 and RN $(p=0.01)$ and the $\mathrm{SN}: \mathrm{RN}$ ratio in EXP2 $(\mathrm{p}=0.05)$. The $\mathrm{N}$ content appears to be a response to plant DW production.

There were significant differences in plant tissue NUE and RAE 
TABLE 3. Plant $N$ accumulation and partitioning of four creeping cultivars (C) in EXP1 (a) and EXP2 (b) grown under low (3 ppm) and high (50 ppm) levels of $\mathrm{N}$.

\begin{tabular}{|c|c|c|c|c|c|c|c|c|}
\hline \multirow[b]{2}{*}{ Cultivar } & \multicolumn{2}{|c|}{ Whole plant $\mathrm{N}$} & \multicolumn{2}{|c|}{ Root N } & \multicolumn{2}{|c|}{ Shoot N } & \multicolumn{2}{|c|}{ SIAN } \\
\hline & Low $N$ & High N & Low $\mathrm{N}$ & High N & Low $N$ & High $N$ & Low $\mathrm{N}$ & High $\mathrm{N}$ \\
\hline \multicolumn{9}{|l|}{ (a) } \\
\hline National & $84,05 \mathrm{a}^{7}$ & $363.22 \mathrm{ab}$ & $18.67 \mathrm{a}$ & $22.05 a$ & 65.38 a & $341.17 \mathrm{ab}$ & $3.70 \mathrm{ab}$ & $16.02 \mathrm{~b}$ \\
\hline SR 1020 & $83.82 \mathrm{a}$ & 300.10 a & $18.00 \mathrm{a}$ & $19.60 \mathrm{a}$ & $65,82 \mathrm{a}$ & $280.50 \mathrm{a}$ & $3.61 \mathrm{ab}$ & $14.63 \mathrm{ab}$ \\
\hline Penncross & $116.22 \mathrm{~b}$ & $472.65 b$ & 28.85 a & $38.07 \mathrm{a}$ & $87.36 \mathrm{a}$ & $434.58 \mathrm{~b}$ & $3.08 \mathrm{a}$ & $11.58 \mathrm{a}$ \\
\hline Putter & $117,88 \mathrm{~b}$ & $288.08 \mathrm{a}$ & 22.11 a & $19.25 \mathrm{a}$ & $95.77 \mathrm{a}$ & $268.83 \mathrm{a}$ & $4.47 \mathrm{~b}$ & $14.74 \mathrm{ab}$ \\
\hline LSD $_{0.05}$ & 23.74 & 127.28 & 5.70 & 9.95 & 19.60 & 118.64 & 0.88 & 3.44 \\
\hline c & & 4 & & & & • & $*$ & \\
\hline${ }_{C}^{N} \times N$ & . & 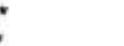 & & & & 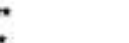 & $*$ & \\
\hline
\end{tabular}

(b)

\begin{tabular}{|c|c|c|c|c|c|c|c|c|}
\hline National & $88.64 \mathrm{a}$ & 580.99 a & $29.46 \mathrm{a}$ & 29,54 a & $59,18 \mathrm{a}$ & 551.44 a & $2.21 a b$ & $19.80 \mathrm{~b}$ \\
\hline SA 1020 & 76.46 a & 500.87 a & $20,48 \mathrm{a}$ & $40.73 a$ & $55.98 \mathrm{a}$ & $460.14 \mathrm{a}$ & $2.78 \mathrm{~b}$ & $12.28 \mathrm{a}$ \\
\hline Penncross & $78.07 \mathrm{a}$ & $644.68 \mathrm{a}$ & $25,68 \mathrm{a}$ & $50.20 \mathrm{~b}$ & $52.40 \mathrm{a}$ & 587.48 a & $208 \mathrm{a}$ & $10.38 \mathrm{a}$ \\
\hline Putter & $81.65 \mathrm{a}$ & 519.84 a & $20.05 \mathrm{a}$ & $40,59 a$ & $59.60 \mathrm{a}$ & $479.25 \mathrm{a}$ & $270 a b$ & $13.44 \mathrm{ab}$ \\
\hline LSD $_{0.05}$ & 26.70 & 144,80 & 9.36 & 15.61 & 20.34 & 136.60 & 0.66 & 6.52 \\
\hline C & \multicolumn{2}{|c|}{ ns } & \multicolumn{2}{|c|}{ • } & \multicolumn{2}{|c|}{ ns } & \multicolumn{2}{|l|}{ - } \\
\hline & \multicolumn{2}{|c|}{$\omega$} & \multicolumn{2}{|c|}{$*$} & \multicolumn{2}{|c|}{$*$} & \multicolumn{2}{|l|}{$*$} \\
\hline $\mathrm{C} \times \mathrm{N}$ & \multicolumn{2}{|c|}{ ns } & \multicolumn{2}{|c|}{$\omega$} & \multicolumn{2}{|c|}{ ns } & \multicolumn{2}{|l|}{ • } \\
\hline
\end{tabular}

Values within a column followed by the same letter are not significantly different at the S\% ievel by Fisher's protested LSD.

$*, \cdots$, ns Significant at $P>0.05, P<0.05$, and $P<0.01$, respectively.

among the four cultivars grown under two levels of $N$ (Table $4 a, 4 b$ ). On a root basis, 'National' was the least $\mathrm{N}$ utilization efficient cultivar under low levels of $\mathrm{N}$ in EXP2. Under high levels of $\mathrm{N}$, there were no significant differences in root, shoot or whole plant NUE among the four cultivars in either experiment. While there were no clear differences in shoot NUE in EXP1, in EXP2 'Penncross' was the most efficient under low $\mathrm{N}$ and 'Putter' was the most efficient under high $\mathrm{N}$. There might be multiple factor(s) affecting the NUE, such as $\mathrm{N}$ absorption, translocation, assimilation, or redistribution rate (Moll et al., 1982).

RAE values were similar under both levels of $\mathrm{N}$ in either experiment, except for 'Penncross' under low $\mathrm{N}$ in EXP2 where it had the 
TABLE 4. The root (RT), shoot (SH), and whole plant (WP) N utilization efficiency (NUE) and root absorption efficiency (RAE) of creeping bentgrass cultivars (C) in EXP1 (a) and EXP2 (b) grown under low (3 ppm) and high (50 ppm) levels of $\mathrm{N}$.

\begin{tabular}{|c|c|c|c|c|c|c|c|c|}
\hline \multirow[b]{2}{*}{ Cultivar } & \multicolumn{2}{|c|}{ WP NUE } & \multicolumn{2}{|c|}{ RT NÚE } & \multicolumn{2}{|c|}{ SHNUE } & \multicolumn{2}{|c|}{ RAE } \\
\hline & Low $\mathrm{N}$ & High N & Low N & High N & Low N & High N & Low $\mathrm{N}$ & High N \\
\hline (a) & \multicolumn{6}{|c|}{ 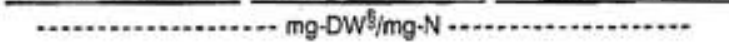 } & \multicolumn{2}{|c|}{$m g-N / m g$ RT-DW } \\
\hline National & $38.92 a^{*}$ & 20.57 a & $48.83 \mathrm{a}$ & $29.98 \mathrm{a}$ & $36.40 \mathrm{a}$ & $19.99 \mathrm{a}$ & $95.68 \mathrm{ab}$ & $570.93 \mathrm{C}$ \\
\hline SR 1020 & $42.56 \mathrm{ab}$ & $21.18 \mathrm{a}$ & $49,66 \mathrm{a}$ & $34.37 \mathrm{a}$ & $41.00 \mathrm{ab}$ & $20.26 \mathrm{a}$ & $92.12 \mathrm{ab}$ & $454.80 \mathrm{ab}$ \\
\hline Penncross & $40.12 \mathrm{a}$ & $20.50 \mathrm{a}$ & $49.16 \mathrm{a}$ & $31,60 \mathrm{a}$ & $37.17 \mathrm{a}$ & $19.57 \mathrm{a}$ & $83.24 \mathrm{a}$ & $402.09 \mathrm{a}$ \\
\hline Putter & $44.95 \mathrm{~b}$ & 20.56 a & $54.37 \mathrm{a}$ & $31.26 \mathrm{a}$ & $42.90 \mathrm{~b}$ & $19.82 \mathrm{a}$ & $102.43 \mathrm{~b}$ & $497.93 \mathrm{bc}$ \\
\hline $\mathrm{LSD}_{0,05}$ & 4.80 & 1.31 & 8.08 & 4.71 & 5.50 & 1.31 & 13.37 & 90.26 \\
\hline $\begin{array}{l}\mathrm{C} \\
\mathrm{N} \\
\mathrm{C} \times \mathrm{N}\end{array}$ & \multicolumn{2}{|c|}{$n s^{*}$} & \multicolumn{2}{|c|}{ ns } & \multicolumn{2}{|c|}{ ns } & \multicolumn{2}{|c|}{$*$} \\
\hline \multicolumn{9}{|l|}{ (b) } \\
\hline Nationa! & $44.64 \mathrm{a}$ & $20.76 \mathrm{a}$ & $50.70 \mathrm{a}$ & $38.18 \mathrm{a}$ & $43.33 \mathrm{a}$ & $19.66 \mathrm{a}$ & $65.03 \mathrm{~b}$ & $535.86 \mathrm{a}$ \\
\hline SR 1020 & $50.88 \mathrm{bc}$ & $21.40 \mathrm{a}$ & $63.28 \mathrm{~b}$ & $32.05 \mathrm{a}$ & $46.45 \mathrm{a}$ & $19.98 \mathrm{a}$ & $60.05 \mathrm{~b}$ & $389,31 \mathrm{ab}$ \\
\hline Penncross & $55.92 \mathrm{c}$ & $21.04 \mathrm{a}$ & $63.29 \mathrm{~b}$ & $32.05 \mathrm{a}$ & $52.60 \mathrm{a}$ & $19.98 \mathrm{a}$ & $48.48 \mathrm{a}$ & $357.31 \mathrm{a}$ \\
\hline Putter & $50.43 \mathrm{~b}$ & 23.17 a & $63,45 \mathrm{~b}$ & $32.79 \mathrm{a}$ & $45.84 \mathrm{a}$ & $22.47 \mathrm{~b}$ & $58.52 \mathrm{~b}$ & $429.71 \mathrm{~b}$ \\
\hline $\mathrm{LSD}_{0.05}$ & 5,45 & 1.86 & 11,95 & 9.64 & 5.36 & 1.89 & 7,35 & 105.63 \\
\hline $\begin{array}{l}\mathrm{C} \\
\mathrm{C} \\
\mathrm{C} \times \mathrm{N}\end{array}$ & $\ddot{*}$ & & ? & & * & & $\ddot{*}$ & 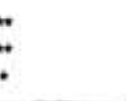 \\
\hline
\end{tabular}

lowest RAE. The RAE value of the cultivars was probably not a response to NUE. Differences in RAE were probably not a critical factor in genotypic differences in NUE. This is indicated only by an increase in the absorption rate of $\mathrm{N}$ per unit weight or volume of the root of high RAE cultivars (Kolek and Kozinka, 1991). This result agrees with Swiader et al. (1994), who found the same results in pumpkin hybrids. Other factors such as NAC or nitrate reductase activity may be more important in the regulation of $\mathrm{N}$ utilization.

Differences among cultivars for NUE were significantly $(p=0.01)$ greater at low $\mathrm{N}$ than high levels of $\mathrm{N}$. Conversely, RAE increased with increasing $\mathrm{N}$ levels $(\mathrm{p}=0.01)$. Higher available $\mathrm{N}$ levels are usually needed to maximize $\mathrm{N}$ uptake to eventually maximize plant 
yield (Bundy and Carter, 1988). The cultivar $\times \mathrm{N}$ level interaction was significant only for whole plant and SNUE $(p=0.01)$ in EXP2 and RAE in both experiments.

An analysis of root nitrate $\mathrm{N}\left(\mathrm{RNO}_{3}-\mathrm{N}\right)$ content of cultivars under the high level of $\mathrm{N}$ showed that 'Penncross' accumulated more $\mathrm{NO}_{3}-\mathrm{N}$ than all the other cultivars while 'Penncross' and 'Putter' had higher $\mathrm{NO}_{3}-\mathrm{N}$ under low $\mathrm{N}$ levels in EXP1 (Table 5a). The measured $\mathrm{NO}_{3}-\mathrm{N}$ content of shoots $\left(\mathrm{SNO}_{3}-\mathrm{N}\right)$ indicated that 'Putter' and 'Penncross' translocated more $\mathrm{SNO}_{3}-\mathrm{N}$ than all the other cultivars in EXP1 under low and high levels of $\mathrm{N}$, respectively.

On a whole plant basis, 'Putter' and 'Penncross' accumulated the highest $\mathrm{NO}_{3}-\mathrm{N}$ in EXP1 under low $\mathrm{N}$ condition. Under high $\mathrm{N}$ condition, 'Penncross' accumulated the most $\mathrm{NO}_{3}-\mathrm{N}$ among the cultivars in EXP1. The cultivars $\times \mathrm{N}$ levels interaction was significant for

TABLE 5. Plant nitrate $\left(\mathrm{NO}_{3}-\mathrm{N}\right)$ accumulation and partitioning of four creeping bentgrass cultivars (C) in EXP1 (a) and EXP2 (b) grown under low ( $3 \mathrm{ppm})$ and high $(50 \mathrm{ppm})$ levels of $\mathrm{N}$.

\begin{tabular}{|c|c|c|c|c|c|c|c|c|}
\hline \multirow[b]{2}{*}{ Cultivar } & \multicolumn{2}{|c|}{ Whole $\mathrm{NO}_{3} \cdot \mathrm{N}$} & \multicolumn{2}{|c|}{$\mathrm{Root} \mathrm{NO}_{3}-\mathrm{N}$} & \multicolumn{2}{|c|}{ Shoot $\mathrm{NO}_{3} \cdot \mathrm{N}$} & \multicolumn{2}{|c|}{$\mathrm{S} / \mathrm{RNO}_{3}-\mathrm{N}$} \\
\hline & Low N & High N & Low N & High N & Low $\mathrm{N}$ & High N & Low N & High N \\
\hline (a) & \multicolumn{8}{|c|}{ (2) } \\
\hline National & $7,59 \mathrm{a}^{\gamma}$ & $42.66 \mathrm{a}$ & $2.05 \mathrm{a}$ & $1.86 \mathrm{a}$ & $5.54 \mathrm{a}$ & $40.81 \mathrm{a}$ & $2.89 \mathrm{~b}$ & 22.64 a \\
\hline SR 1020 & $7.32 a$ & $32.92 \mathrm{a}$ & $2.05 a$ & $1.95 \mathrm{a}$ & $5.26 \mathrm{a}$ & $34.98 \mathrm{a}$ & $2.65 a b$ & $18.23 \mathrm{a}$ \\
\hline Penncross & $9.73 \mathrm{~b}$ & $58.42 \mathrm{~b}$ & $3.27 \mathrm{~b}$ & $2.82 \mathrm{~b}$ & $6.46 \mathrm{a}$ & $55.80 \mathrm{~b}$ & $2.02 \mathrm{a}$ & 20.71 a \\
\hline Putter & $10.77 \mathrm{~b}$ & $30.98 \mathbf{a}$ & $2.89 \mathrm{~b}$ & $1.67 \mathrm{a}$ & $7.89 \mathrm{~b}$ & $29.31 \mathrm{a}$ & $2.96 \mathrm{~b}$ & $21.08 \mathrm{a}$ \\
\hline $\mathrm{LSD}_{0,05}$ & 1.81 & 13.70 & 0.82 & 0.83 & 1.22 & 13.24 & 0.77 & 7.61 \\
\hline C & \multicolumn{2}{|c|}{$\star *+7$} & \multicolumn{2}{|c|}{$*$} & \multicolumn{2}{|c|}{$*$} & \multicolumn{2}{|c|}{ ns } \\
\hline $\mathrm{N}$ & \multicolumn{2}{|c|}{$*$} & \multicolumn{2}{|c|}{$*$} & \multicolumn{2}{|c|}{$\star *$} & \multicolumn{2}{|c|}{$*$} \\
\hline $\mathrm{C} \times \mathrm{N}$ & \multicolumn{2}{|c|}{ *n } & \multicolumn{2}{|c|}{ ns } & \multicolumn{2}{|c|}{ *n } & \multicolumn{2}{|c|}{ ns } \\
\hline \multicolumn{9}{|l|}{ (b) } \\
\hline National & 6.39 a & $72.28 a b$ & $2.54 \mathrm{a}$ & $5.05 \mathrm{a}$ & $3.85 \mathrm{a}$ & $67.24 \mathrm{ab}$ & $1,88 \mathrm{ab}$ & $24.30 \mathrm{a}$ \\
\hline SR 1020 & $5,87 \mathrm{a}$ & 55.98 a & $2.30 \mathrm{a}$ & $2.91 \mathrm{a}$ & $3.57 \mathrm{a}$ & $53.08 \mathrm{a}$ & $1.88 \mathrm{ab}$ & 20.48 a \\
\hline Penncross & $5.73 \mathrm{a}$ & $85,12 b$ & $2.73 \mathrm{a}$ & $5.66 \mathrm{a}$ & $3.00 \mathrm{a}$ & $79.46 \mathrm{~b}$ & $1.15 \mathrm{a}$ & $17.08 \mathrm{a}$ \\
\hline Putter & $5.45 \mathrm{a}$ & $86.61 \mathrm{~b}$ & $1.74 \mathrm{a}$ & $5.13 a$ & $3.71 \mathrm{a}$ & $81.48 \mathrm{a}$ & $2.14 b$ & $24.02 \mathrm{a}$ \\
\hline $\mathrm{LSD}_{0,05}$ & 2.46 & 18.97 & 1.40 & 3.51 & 1.41 & 19.87 & 0.77 & 18.74 \\
\hline C & \multicolumn{2}{|c|}{$*$} & \multicolumn{2}{|c|}{ ns } & \multicolumn{2}{|c|}{$\cdot$} & \multicolumn{2}{|c|}{ ns } \\
\hline $\mathrm{N}$ & \multicolumn{2}{|c|}{$*$} & \multicolumn{2}{|c|}{ * } & \multicolumn{2}{|c|}{$*$} & \multicolumn{2}{|c|}{$*$} \\
\hline $\mathrm{C} \times \mathrm{N}$ & \multicolumn{2}{|c|}{$*$} & \multicolumn{2}{|c|}{ ns } & \multicolumn{2}{|c|}{$\cdot$} & \multicolumn{2}{|c|}{ ns } \\
\hline
\end{tabular}

FValues within a column followed by the same letter are not significantly different at the $5 \%$ level by Fisher's protested LSD.

$\neq, \cdots$, nsignificant at $P>0.05, P<0.05$, and $P<0.01$, respectively. 
$\mathrm{WNO}_{3}-\mathrm{N}$ and $\mathrm{SNO}_{3}-\mathrm{N}$ total $(\mathrm{p}=0.05)$ in both experiments. The $\mathrm{NO}_{3}-\mathrm{N}$ content in plant tissues was a response to the $\mathrm{N}$ content accumulated in plant tissue.

An analysis of reduced $\mathrm{RN}$ for cultivars under both $\mathrm{N}$ levels showed that 'Penncross' accumulated the most reduced RN in EXP1 (Table 6a, $6 \mathrm{~b})$. Reduced SN indicated that 'Putter' and 'Penncross' accumulated more reduced $\mathrm{N}$ among the other cultivars under low levels of $\mathrm{N}$ in EXP1.

There was little difference in $\mathrm{RN} / \mathrm{TN}$ ratio among the four cultivars under either level of $\mathrm{N}$ in both experiments, with $\mathrm{RN}$ accounting for approximately $90 \%$ of the TN in plant tissues. In EXP2, 'Putter' had a significantly lower RN/TN ratio among the four cultivars for both shoot and whole plant evaluations. The cultivar $\times \mathrm{N}$ level interaction was significant for shoot $(p=0.05)$ reduced $N$ in EXP1, and root reduced $\mathrm{N}(\mathrm{p}=0.01)$, and also shoot and total RN/TN $(p=0.05)$ in EXP2.

The environmental effects were substantial. The highly significant Nutilization $\times$ environment interaction (Table 7) indicated that plants response to $\mathrm{N}$ fertilizer was different in the two different environments. The studies were conducted twice in July and November. In the first experiment, turf plants were grown under high temperatures and did not grow vigorously. The season was not suitable for the growth of cool season turfgrasses. In the second experiment, the optimal temperature allowed the turf plants to grow fast and vigorously. This was probably one of the explanations that the WPDW in EXP2 was greater than that found in EXP1, although there was no statistic differences under low levels of $\mathrm{N}$. N supply was a dominate factor to influence the dry matter production. Root absorption efficiency under unlimited $\mathrm{N}$ supply seems not to be influenced by environmental factors. These results agree with the studies by Balko and Russell (1980), who found that differences in response among maize cultivars exist with respect to the season of the year and rate of $\mathrm{N}$ application. In EXP1. The S/R NRA ratio was less than one (Table 8 ), however, the $S / R$ ratio was more than one in EXP2. The results indicated that the environment affected the sites of nitrate assimilation and reductase activity. It seemed that under hot summers the plants may gain no energetic advantage from leaf assimilation, thus, made SNRA higher in EXP2. This result agrees with Stewart et al. (1986), who reported with ferns grown under shady conditions, the root was the site of nitrate assimilation, conversely, under sunny conditions nitrate was assimilated both 
TABLE 6. Accumulation of reduced $N(R N)$ and the ratio of reduced $N$ to total $\mathrm{N}(\mathrm{RN} / \mathrm{TN}$ ) of creeping bentgrass cultivars (C) grown under different levels of $\mathrm{N}$ in EXP1.

\begin{tabular}{|c|c|c|c|c|c|c|c|}
\hline \multirow{3}{*}{$\begin{array}{l}\text { Cultivar } \\
\text { (a) }\end{array}$} & \multirow{3}{*}{$\begin{array}{c}\text { N level } \\
\text { (ppm) }\end{array}$} & \multicolumn{2}{|c|}{ Root RN } & \multicolumn{2}{|c|}{ Shoot RN } & \multicolumn{2}{|c|}{ Total RN } \\
\hline & & $(m g)$ & $\mathrm{RN} / \mathrm{TN}$ & $(\mathrm{mg})$ & $\mathrm{RN} / \mathrm{TN}$ & (mg) & RN/TN \\
\hline & & & & & & & \\
\hline National & \multirow[t]{5}{*}{3} & $16.62 \mathrm{a}^{\dagger}$ & $0,69 a$ & 59.84 a & $0,92 \mathrm{a}$ & $76,46 a$ & $0.91 \mathrm{a}$ \\
\hline Sr 1020 & & 15.95 a & $0.89 \mathrm{a}$ & 60.568 & $0.92 \mathrm{a}$ & $76.50 \mathrm{a}$ & $0.91 \mathrm{a}$ \\
\hline Penncross & & $25.60 \mathrm{~b}$ & $0.89 a$ & $80.89 \mathrm{a}$ & $0.83 \mathrm{a}$ & $106,49 \mathrm{~b}$ & $0.82 \mathrm{a}$ \\
\hline Putter & & $19.23 \mathrm{a}$ & $0.87 \mathrm{a}$ & $87.88 \mathrm{~b}$ & $0.91 \mathrm{a}$ & $107.11 \mathrm{~b}$ & $0.81 \mathrm{a}$ \\
\hline LSD 0.05 & & 5.28 & 0.03 & 18.98 & 0.02 & 22.70 & 0.02 \\
\hline National & \multirow[t]{7}{*}{50} & $20.19 \mathrm{a}$ & $0.92 \mathrm{ab}$ & $300.36 \mathrm{ab}$ & $0.88 \mathrm{a}$ & $320.55 \mathrm{ab}$ & $0.88 \mathrm{a}$ \\
\hline SP 1020 & & $17.65 \mathrm{a}$ & $0.90 \mathrm{a}$ & $245.52 \mathrm{a}$ & $0.88 \mathrm{a}$ & $263.18 \mathrm{a}$ & 0.88 a \\
\hline Penncross & & $35.25 \mathrm{~b}$ & $0.93 \mathrm{~b}$ & $378.98 \mathrm{~b}$ & 0.87 a & $414.22 \mathrm{~b}$ & $0.87 \mathrm{a}$ \\
\hline Putter & & $17.58 \mathrm{a}$ & $0.91 \mathrm{ab}$ & 239.51 a & $0.89 \mathrm{a}$ & 257.09 a & 0.89 a \\
\hline LSD 0.05 & & 9.26 & 0.02 & 108.82 & 0.03 & 116.97 & 0.03 \\
\hline C & & t.8 & ns & $\dot{*}$ & ns & $\dot{*}$ & $n s$ \\
\hline$\stackrel{N}{C} \times N$ & & $\begin{array}{l}\text { ns } \\
\text { ns }\end{array}$ & ns & $\ddot{*}$ & ns & ns & ns \\
\hline \multicolumn{8}{|l|}{ (b) } \\
\hline National & \multirow[t]{5}{*}{3} & $26.91 \mathrm{~b}$ & 0.92 a & $55.33 \mathrm{a}$ & 0.94 a & $82.24 \mathrm{a}$ & $0.83 \mathrm{a}$ \\
\hline Sr 1020 & & $18.18 \mathrm{a}$ & $0.89 \mathrm{a}$ & $52.41 \mathrm{a}$ & $0.94 \mathrm{a}$ & 70.59 a & $0.92 \mathrm{a}$ \\
\hline Penncross & & $22.95 \mathrm{ab}$ & $0.89 \mathrm{a}$ & 49.39 a & $0.94 a$ & $76.20 \mathrm{a}$ & 0.93 a \\
\hline Putter & & $20.31 \mathrm{ab}$ & $0.92 \mathrm{a}$ & $55.89 \mathrm{a}$ & $0.94 a$ & $76.20 \mathrm{a}$ & $0.93 \mathrm{a}$ \\
\hline LSD 0.05 & & 8.41 & 0.04 & 19.16 & 0.01 & 24.61 & 0.02 \\
\hline National & \multirow[t]{5}{*}{50} & $24,50 \mathrm{ab}$ & $0.81 \mathrm{a}$ & $484.21 \mathrm{a}$ & $0.88 \mathrm{~b}$ & $508.71 \mathrm{a}$ & $0.87 \mathrm{~b}$ \\
\hline SR 1020 & & $37,83 a b$ & $0.93 \mathrm{~b}$ & $407,06 \mathrm{a}$ & $0.88 \mathrm{~b}$ & 444,89 a & $0.89 \mathrm{~b}$ \\
\hline Penncross & & 51.54 b & $0.90 \mathrm{ab}$ & $508.02 \mathrm{a}$ & $0.87 \mathrm{~b}$ & $559.56 \mathrm{a}$ & $0.87 \mathrm{~b}$ \\
\hline Putter & & $35.46 \mathrm{a}$ & $0,87 a b$ & $397.77 \mathrm{a}$ & $0.83 a$ & 433.23 a & $0.83 \mathrm{a}$ \\
\hline LSD 0.05 & & 15.34 & 0.11 & 128.40 & 0.04 & 137.53 & 0.04 \\
\hline C & & $\cdot$ & ns & ns & $\bullet$ & ns & ns \\
\hline $\mathrm{N}$ & & $*$ & ns & 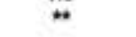 & $*$ & $*$ & $\omega$ \\
\hline $\mathrm{C} \times \mathrm{N}$ & & $\Leftrightarrow$ & ns & ns & $*$ & ns & $*$ \\
\hline
\end{tabular}

Values within a column followed by the same letter are not significantly different at the $5 \%$ level by Fisher's protested LSD.

$\mp * *$, ns Significent at $P>0.05, P<0.05$, and $P<0.01$, respectively.

in the root and shoot. The site of nitrate assimilation may be influenced by environmental conditions, such as temperature. There was no correlation between $\mathrm{NO}_{3}-\mathrm{N}$ content and NRA in the experiments. For the NRA assay, the $0.5 \mathrm{~g}$ samples tested were derived from the tip portions of organs, so the level of nitrate accumulated in this portion might not represent a general WPNO${ }_{3}-\mathrm{N}$ content. 
TABLE 7. Effect of experimental timing (two environments) on whole plant dry weight (DW) accumulation, $N$ accumulation, $N$ utilization efficiency (NUE), root absorption efficiency (RAE), nitrate accumulation $\left(\mathrm{NO}_{3}\right)$, reduced $\mathrm{N}(\mathrm{RN})$, nitrate assimilatory capacity (RN/TN), root nitrate reductase activity (RT NRA), and shoot nitrate reductase activity (SH NRA) evaluated under low and high levels of $\mathrm{N}$.

\begin{tabular}{lccccccccc}
\hline Treatments & $\mathrm{DW}$ & $\mathrm{N}$ & $\mathrm{NUE}$ & $\mathrm{RAE}$ & $\mathrm{NO}_{3}{ }^{-}$ & $\mathrm{RN}$ & $\mathrm{RN} / \mathrm{TN}$ & RT NRA & SH NRA \\
\cline { 2 - 9 } low & $\mathrm{ns}^{\dagger}$ & $*$ & $*$ & $*$ & $*$ & $*$ & $*$ & $*$ & $*$ \\
high & $*$ & $*$ & $*$ & ns & $*$ & $*$ & $*$ & $*$ & $*$ \\
\hline
\end{tabular}

ns, $* *$ Signilicant at $P>0.05, P<0.05$, and $P<0.01$, respectively.

TABLE 8. Plant tissue nitrate reductase activity (NRA) and partitioning of four creeping bentgrass cultivars (C) in EXP1 (a) and EXP2 (b) grown under low (3 $\mathrm{ppm})$ and high $(50 \mathrm{ppm})$ levels of $\mathrm{N}$.

\begin{tabular}{|c|c|c|c|c|c|c|}
\hline \multirow{3}{*}{$\begin{array}{l}\text { Cultivar } \\
\text { (a) }\end{array}$} & \multicolumn{2}{|c|}{ Root NRA } & \multicolumn{2}{|c|}{ Shoot NRA } & \multicolumn{2}{|c|}{ S/R NAA } \\
\hline & Low & High & Low & High & Low & High \\
\hline & \multicolumn{6}{|c|}{. } \\
\hline National & $0.09 \mathrm{a}^{+}$ & $1.96 \mathrm{a}$ & 0.01 a & $0.18 a b$ & $0.16 a$ & $0.09 a$ \\
\hline SR 1020 & $0.12 \mathrm{~b}$ & $1.28 \mathrm{a}$ & $0.02 \mathrm{a}$ & $0.16 \mathrm{ab}$ & $0.14 \mathrm{a}$ & 0.15 a \\
\hline Penncross & $0.10 \mathrm{ab}$ & $1.28 \mathrm{a}$ & $0.03 \mathrm{a}$ & 0.05 a & $0.29 \mathrm{a}$ & $0.04 \mathrm{a}$ \\
\hline Putter & $0.09 \mathrm{a}$ & $1.50 \mathrm{a}$ & 0.01 a & $0.24 b$ & $0.16 \mathrm{a}$ & $0.17 \mathrm{a}$ \\
\hline LSD 0.05 & 0.03 & 1.13 & 0.03 & 0.16 & 0.31 & 0.18 \\
\hline $\begin{array}{l}\mathrm{C} \\
\mathrm{N} \\
\mathrm{C} \times \mathrm{N}\end{array}$ & & & & & & \\
\hline \multicolumn{7}{|l|}{ (b) } \\
\hline National & 0.15 a & $0.77 \mathrm{a}$ & $0.19 a$ & $0.57 \mathrm{a}$ & $1.25 \mathrm{a}$ & $1.07 \mathrm{a}$ \\
\hline SR 1020 & $0.22 \mathrm{a}$ & $0.88 \mathrm{a}$ & $0.24 \mathrm{a}$ & $0.78 \mathrm{a}$ & $1.07 \mathrm{a}$ & $1.49 \mathrm{a}$ \\
\hline Penncross & $0.25 \mathrm{a}$ & $1.19 \mathrm{a}$ & $0.27 \mathrm{a}$ & $0.82 \mathrm{a}$ & $1.06 \mathrm{a}$ & $0.70 \mathrm{a}$ \\
\hline Putter & $0.26 \mathrm{a}$ & 0.88 a & $0.29 \mathrm{a}$ & $1.05 \mathrm{a}$ & $1.49 \mathrm{a}$ & $1.41 \mathrm{a}$ \\
\hline LSD 0.05 & 0.16 & 0.75 & 0.21 & 0.77 & 1.04 & 1.57 \\
\hline C & \multicolumn{2}{|c|}{ ns } & \multicolumn{2}{|c|}{ ns } & \multicolumn{2}{|c|}{ ns } \\
\hline $\begin{array}{l}\mathrm{N} \\
\mathrm{C} \times \mathrm{N}\end{array}$ & \multirow{2}{*}{\multicolumn{2}{|c|}{ ns }} & & & & \\
\hline$C \times N$ & & & \multicolumn{2}{|c|}{ ns } & \multicolumn{2}{|c|}{ ns } \\
\hline
\end{tabular}

TValues within a column followed by the same letter are not signilicantly different at the $5 \%$ level by Fisher's protested LSD.

$\mp ?+$, ns Signilicant at $P>0.05, P<0.05$, and $P<0.01$, respectively. 
These results demonstrated genotypic variation in $\mathrm{N}$ utilization and absorption. In general, 'Putter' and 'Penncross' were the most efficient genotypes in utilizing $\mathrm{N}$ at low $\mathrm{N}$ conditions but had poor RAE. In contrast, 'National' was a poor $\mathrm{N}$ utilization efficient cultivar but had higher efficient absorbed $\mathrm{N}$ among the four cultivars. The $\mathrm{N}$ assimilation capacity was not the primary factor involved in genotypic differences in NUE, however, NRA was probably one of the mechanisms for the regulation of NUE. The NRA was influenced by environmental conditions. It seems that some limitations in growth can occur at certain times of day or season (Goodman, 1983). In future work, more replications of each treatment should be added. Sample selection for NRA assay must be from more uniform growth vegetative stages of the turf plant.

\section{In Vitro Culture}

After four weeks, the explants were producing shoots and roots when grown on different levels of $\mathrm{N}$ supplemented media. The effects of Nitrate concentration on plant growth is shown in Table 9. Plants grown under low $\mathrm{N}$ showed longer root length than plants grown under either medium or high levels of $\mathrm{N}$. These observations agree with Kolek and Kozinka (1991). Boeker and Boberfeld (1974) found that increasing concentrations of $\mathrm{N}$ in the root environment reduces the root extension for some turfgrass cultivars. The reasons probably were: (1) Plant roots growing under N deficiency "search" for nutrient by penetrating deeper in the medium. (2) High concentrations of $\mathrm{N}$ that retard root elongation may be related to changes in growth hormones. Changes in phyto/hormone balance between shoot and root,

TABLE 9. The effect of nitrate concentrations on root length, shoot length, and root number of two creeping bentgrass cultivars 'Putter' and 'National' after incubated in tissue culture for four weeks.

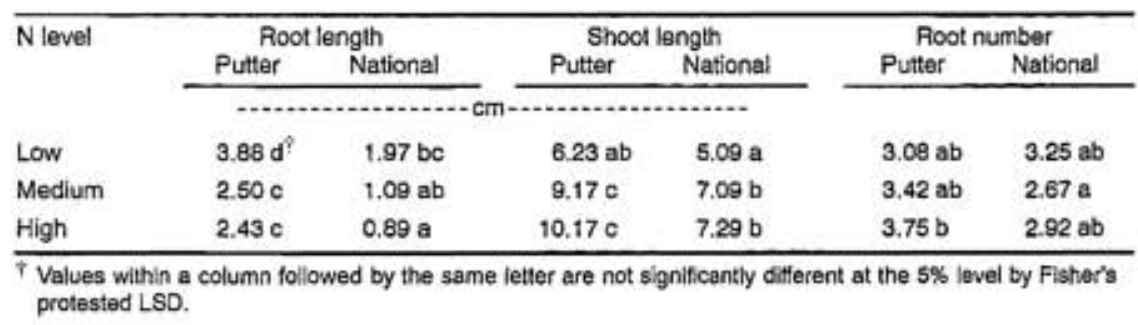


such as auxin, or cytokinin were thought to be involved in this regulation. (3) Under $\mathrm{N}$ deficiency, stronger competition by the roots for photosynthates is regulated by the shoot : root ratio. Conversely, plants grown under low levels of $\mathrm{N}$, they had shorter shoots than plants grown under higher levels of $\mathrm{N}$ for both cultivars. Nitrogen assimilation requires carbohydrates, thus, excess $\mathrm{N}$ will reduce carbohydrate reserves in the root. This was probably one of the reasons for slow root growth. our results agree with Goss and Law (1967), who revealed that high levels of $\mathrm{N}$ resulted in more shoot dry weight of Kentucky bluegrass cultivars under field conditions.

A high NUE cultivar, 'Putter', showed longer root and shoot length than the low NUE cultivar, 'National', for each level of N (Table 9). The higher NUE cultivar could use $\mathrm{N}$ more efficiently in the development of their vegetative organs. The results agree with Feil et al., (1990), who found the root surface area of maize was greatest at low levels of N. Low input (high NUE) cultivars had higher shoot and root dry weight than did high input (low NUE) cultivars. Our investigation suggested that root formation plays an important physiological role in regulating nitrate utilization in creeping bentgrass. The mean root numbers did not show significant differences for either cultivar grown under each level of N (Table 9). Root numbers may not be a stable, specific criterion representing root growth conditions. Future work needs to establish if differences occurred among plants due to plant age, because our investigation materials at the seedling stage.

Increasing $\mathrm{N}$ concentration in the root environment decreases root elongation and increases shoot length. High NUE cultivars also showed longer root and shoot length than low NUE cultivars, but the root numbers were not related. Root formation was probably one of the mechanisms for regulating nitrate utilization in creeping bentgrass.

\section{REFERENCES}

Agnew, M.L. 1992. Natural organic nitrogen sources. Golf Course Management March:70-75.

Andrew, M. 1986. The partitioning of nitrate assimilation between root and shoot of higher plants. Plant Cell and Environ. 9:511-519.

Bar-Akin, A., J. Sagir, and J. Leshem. 1970. Nitrate reductase activity as an indicator for assessing the nitrogen requirement of grass crops. J. Sci. Food Agric. 21:405-407.

Balko, L.G., and W.A. Russell. 1980. Response of maize inbred lines to $\mathrm{N}$ fertilizer. Agron. J. 72:723-728. 
Beard, J.B. 1973. Turfgrass: Science and Culture. Prentice-Hall, Inc. Englewood Cliffs, NJ.

Boeker, P. 1974. Root development of selected turfgrass species and cultivars. pp. 55-61. In: Proc. Second Int. Turfgrass. Res. Conf. Amer. Soc. Agron., Madison, WI.

Bole, J.B. 1993. Influence of root hairs in supplying soil phosphorus to wheat. Can J. Soil Sci. 53(2):169-175.

Bundy, L.G., and P.R. Carter. 1988. Corn hybrid response to nitrogen fertilization in the northern corn belt. J. Prod. Agric. 1:99-104.

Cataldo, D.A., L.E. Schrader, and V.L. Youngs. 1974. Analysis by digestion and colorimetric assay of total nitrogen in plant tissues high in nitrate. Crop Sci. $14: 854-856$.

Cataldo, D.A., M. Haroon, L.E. Schrader, and V.L. Youngs. 1975. Rapid colorimetric determination of nitrate in plant tissue by nitration of salicylic acid. Cammum. Soil Sci. Plant Anal. 6(1):71-80.

Chu, C.C., C.C. Wang, C.A. Sun, C. Hsu, K.C. Yin, C.Y. Chu, and F.Y. Bi. 1975. Establishment of an efficient medium for anther culture of rice through comparative experiments on the nitrogen sources. Scientia Sinica: 18:659-668.

Decker, H.F, and J.M. Decker. 1988. Grasses. p. 69. In: Lawn Care. Prentic Hall, Inc. Englewood Cliffs, NJ.

Evans, N.E. 1993. A Preliminary study on the effects of nitrogen supply on the growth in Vitro of nine potato genotypes (Solanum spp.). J. Exp. Bot. 261:837-841.

Feil, B., R. Thiraporn, G. Geisler, and P. Stamp. 1990. Root traits of maize seedlingsindicators of nitrogen efficiency. pp. 97-101. In: Genetic Aspects of Plant Mineral Nutrition. Ed: N. El Bassam et al. Kluwer Academic Publishers. Netherlands.

Feil, B., R. Thiraporn, G. Geisler, and P. Stamp. 1993. In vitro nitrate reductase activity of laboratory-grown seedlings as an indirect selection criterion for maize. Crop Sci. 33:1280-1286.

Foehse, D., and A. Jungk. 1983. Influence of phosphate and nitrate supply on root hair formation of rape, spinach and tomato plants. Plant and Soil. 74:359-368.

Goodman, P.J. 1983. Genetic variation in nitrogen nutrition of grasses and cereals: possibilities of selection. pp. 447-452. In: Genetic Aspects of Plant Nutri. Ed: N. El Bassam et al. Kluwer Academic Publishers. Netherlands.

Goss, R.L., and A.G. Law. 1967. Performance of bluegrass varieties at two cutting heights and two nitrogen levels. Agron. J. 59:516-518.

Harper, J.E., and R.H. Hageman. 1972. Canopy and seasonal profiles of nitrate reductase in soybeans (Glycine max L. Merr). Plant Physiol. 49:146-154.

Ingemarsson, B. 1987. Nitrogen utilization in Lemna. Plant Physiol. 85:856-859.

Kolek, J., and V. Kozinka. 1991. The root as an integral part of the plant. p. 8. In: Physiology of The Plant Root System. Kluker Academic Publishers. Boston, MA.

Kuo, Y., M.A.L. Smith, and L.A. Spomer. 1994. Merging callus level and whole plant microculture to select salt-tolerant 'Seaside' creeping bentgrass. J. Plant Nutri. 17(4):549-560.

Moll, R.H., E.J. Kamprath, and W.A. Jackson. 1982. Analysis and interpretation of factors which contribute to efficiency of nitrogen utilization. Agron. J. 74:562-564.

Pellett, R.M., and E.C. Roberts. 1963. Effects of mineral nutrition on high temperature induced growth retardation of Kentucky bluegrass. Agron. J. 55:474-476. 
Robison, D. 1986. Limits to nutrient inflow rates in roots and root systems. Physiol. Plant. 68:551-559.

Smimoff, N., P. Todd, and G.R. Stewart. 1984. The occurrence of nitrate reduction in the leaves of woody plants. Ann. Bot. 54:363-374.

Stewert, G.R., N. Sumar and M. Patel. 1987. Comparative aspects of inorganic nitrogen assimilation in higher plants. pp. 39-44. In: Inorganic Nitrogen Metabolism. Springer-Veriah Ed. W.R. Ullrich, J.R. Porter, and D.W. Lawlor. In: Plant Growth-Interactions with Nutrient Ion and Environment. Cambridge University Press, NY.

Stewart, G.R., M. Popp, I. Holzapfel, J.A. Stewart, and A. Dickie-Eskew. 1986. Localization of nitrate reduction in ferns and its relationship to environment and physiological characteristics. New Physiologist. 104:375-384.

Swiader, J.M., Y. Chyan, and F.G. Freiji. 1994. Genotypic differences in nitrate uptake and utilization efficiency in pumpkin hybrids. J. Plant Nutri. 17:1687-1699.

Warncke, D.D., and S.A. Barber. 1974. Nitrate uptake effectiveness of four plant species. Environ. Qual. 1:28-30. 